\title{
Aspek Kriminologis Dalam Penanggulangan Kejahatan
}

\author{
Saleh Muliadi
}

Dosen Fakultas Hukum Universitas Tadulako, Palu

\begin{abstract}
Abstrak
Suatu negara hukum (rechts staat), peranan hukum menempati kedudukan yang utama apabila hukum tersebut dapat melaksanakan fungsi, sebagaimana yang digariskan dalam konstitusi kita yakni melindungi segenap bangsa Indonesia dan seluruh tumpah darah Indonesia. Tugas pemerintah yakni menciptakan instrumen sosial untuk melindungi segenap bangsa Indonesia dari berbagai tindakan yang menimbulkan kerugian. Untuk menjelaskan fenomena kejahatan ada tiga aliran pemikiran, yaitu kriminologi klasik bahwa kejahatan dan penjahat pada umumnya dipandang dari sudut hukum artinya kejahatan adalah perbuatan yang dilarang oleh undang-undang dan penjahat adalah orang yang melakukan kejahatan, kriminologi positivis yaitu mengarahkan usaha untuk menganalisis sebab-sebab prilaku kejahatan melalui studi ilmiah, dan kriminologi kritis yaitu tidak berusaha menjawab persoalan-persoalan apakah prilaku manusia bebas ataukah ditentukan, akan tetapi lebih mengarahkan pada proses-proses yang dilakukan oleh manusia dalam membangunan dunianya dimana dia hidup. Penanggulangan kejahatan tentu mencari faktor yang dapat menimbulkan kejahatan, sehingga dengan penemuan faktor-faktor menimbulkan kejahatan dapat memberi bahan untuk menyusun penanggulangan kejahatan.
\end{abstract}

Kata Kunci : Penanggulangan Kejahatan

\section{Pendahuluan}

Sebagai suatu negara hukum (rechts stat) peranan hukum menempati kedudukan yang utama /tinggi (supermacy of law) apabila hukum tersebut dapat melaksanakan fungsi primernya yakni : ${ }^{1}$

1. Perlindungan, hukum mempunyai fungsi untuk melindungi masyarakat dari ancaman bahaya dan tindakan-tindakan yang merugikan yang datang dari sesamanya dan kelompok masyarakat, termasuk dilakukan

${ }^{1}$.I.S.Susanto, 1999, Paradigma Hukum Yang Berdaulat Dalam Wacana Politik Hukum dan Demokrasi Indonesia, Editor, M.A.S.Hikam dan Mulyana W.Kusumah, Pustaka Pelajar, Yogyakarta, hal.125-126 oleh pemegang kekuasaan (pemerintah dan negara) dan yang datang dari luar yang ditujukan terhadap fisik, jiwa, kesehatan, nilai-nilai dan hak-hak asasinya.

2. Keadilan, fungsi lain dari hukum adalah menjaga, melindungi, dan memberikan keadilan bagi seluruh rakyat, secara negatif dapat dikatakan bahwa hukum yang bersangkutan dipandang melanggar nilai-nilai dan hak-hak yang kita percayai harus dijaga dan dilindungi bagi semua orang.

3. Pembangunan, fungsi hukum yang ketiga adalah pembangunan, dalam rangka mewujudkan kesejahteraan bagi seluruh rakyat Indonesia. Ini mengandung makna bahwa pembangunan di 
Indonesia sepenuhnya untuk meningkatkan kesejahteraan rakyat disegala aspek klehidupan ekonomi, politik, budaya, dan spritual.

Dengan demikian, hukum dipakai sebagai kendaraan dalam menentukan arah, tujuan dan pelaksanaan pembangunan secara adil. Artinya, hukum sekaligus digunakan sebagai alat pembangunan dan sebagai alat kontrol agar pembangunan dilaksanakan secara adil.

Fungsi hukum ini dijalankan guna mencapai tujuan yang digariskan dalam konstitusi kita yakni melindungi segenap bangsa Indonesia dan seluruh tumpah darah Indonesia. Berdasarkan hal itu, tugas pemerintah yakni menciptakan instrumen sosial untuk melindungi segenap bangsa Indonesia dari berbagai tindakan yang menimbulkan kerugian.

Implementasi persyararatan melalui instrumen sosial seperti penciptaan norma-norma hukum hendaknya memperhatikan perkembangan sosial dalam masyarakat itu sendiri dengan memberikan kepastian dan prediktabilitas terhadap perbuatanperbuatan yang diperkirakan akan menimbulkan permasalahan sosial yang serius, misalnya upaya penanggulangan meluasnya kejahatan, yang oleh sebab itu penanggulangan dan penciptaan kebijakan (policy/kriminal) harus diperhitungkan secara cermat dan dilaksanakan secara konsisten. $^{2}$

\footnotetext{
${ }^{2}$.Barda Nawawi Arief, Masalah penegakan Hukum dan Kebijakan Hukum Pidana
}

Dalam forum Internasional khsusnya dalam perkembangan Kongres PBB mengurai "The Prevention of Crime and The Treatment of Offenders", Masalah pencegaha/penanggulangan kejahatan lebih banyak dilihat dari konteks kebijakan pembangunan / sosial global.

Adapun strategi kebijakan penanggulangan / pencegahan kejahatan menurut Kongres PBB pada garis besarnya sebagai berikut:

a. Strategi dasar / pokok penanggulangan kejahatan, ialah meniadakan faktor-faktor penyebab / kondisi yang menimbulkan terjadinya kejahatan.

b. Pencegahan kejahatan dan peradilan pidana harus ditempuh dengan kebijakan integral/sistematik. ${ }^{3}$

Kejahatan sebagai masalah sosial tampaknya tidak hanya merupakan masalah bagi suatu masyarakat tertentu (nasional), tetapi juga menjadi masalah yang dihadapi oleh seluruh masyarakat di dunia, hal itu telah merupakan fenomena Internasional atau menurut istilah Sciichiro Ono merupakan universal phenomenon. $^{4}$

Pemahaman kejahatan pada masa lampau sering kali kehilangan maknanya karena melepaskan dirinya dari konsep masyarakat sebagai suatu totalitas yakni dari

Dalam menanggulangi Kejahatan, Kencana Pernada Media Group, Jakarta 2007, hal.81

3 .Barda Nawawi Arief, 2007, Ibid, hal.81

${ }^{4}$.Departement of Economic and Social Affairs, Fourrth United Nations Congress on The Prevention of Crime, New York, 1971, hal. 7 
tempat kejadian dan pemahaman kejahatan itu, sedangkan kejahatan sebagai gejala sosial selalu merupakan kejahatan dalam masyarakat yang merupakan keseluruhan proses-proses sosial, budaya, politik, ekonomi, dan struktur yang ada di dalamnya, dan yang kesemuanya merupakan hasil dari sejarah hubungan antar manusia.

Dengan demikian untuk dapat memahami masalah kejahatan di negara kita, perlu diperhatikan pula keseluruhan proses-proses tersebut di atas yang terjadi di masyarakat. Hal ini mengingat pengertian kejahatan yang relatif dan jauh dari pengertian yang absolut.

\section{Pembahasan}

\subsection{Pengertian Kriminologi dan}

\section{Kejahatan}

Kriminologi merupakan ilmu pengetahuan yang mempelajari tentang kejahatan. Secara etimologi kriminologi berasal dari kata "Crime" yang bearti kejahatan dan "logos" yang berarti pengetahuan atau ilmu pengetahuan, sehingga kriminologi adalah ilmu tentang kejahatan atau penjahat. Istilah kriminologi itu sendiri untuk pertama kali dipergunakan oleh seorang ahli antropologi dari Perancis yaitu P.Topinar. Sthepen Hurwitz, memandang kriminologi sebagai bagian dari criminal scaince yang dengan penelitian empiris atau nyata berusaha memberikan gambaran tentang faktor-faktor kriminalitas.

W.A.Bonger memberikan defenisi kriminologi sebagai ilmu

\footnotetext{
5 .Sthephan Hurwitz, 1982, Kriminologi, Disadur Oleh Ny.L.Moeljatno, Bina Aksara, Jakarta, hal9
}

pengetahuan yang bertujuan menyelidiki gejala kejahatan seluasluasnya. ${ }^{6}$ Defenisi Bonger, membagi kriminologi menjadi kriminologi murni yang mencakup antara lain; antropologi kriminil, sosiologi kriminil, psikologi kriminil, psikoneuropathologi kriminil, statistik kriminil dan poenologi. Bagianbagian kriminologi tersebut mengandung rumusan sesuai dengan bidang obyeknya masing-masing yaitu:

1. Antropologi kriminil, ialah ilmu pengetahuan tentang manusia yang jahat (somatis), ilmu pengetahuan ini memberikan jawaban atas pertanyaan tentang orang jahat dalam tubuhnya mempunyai tanda-tanda seperti apa, apakah ada hubungan antara suku bangsa dengan kejahatan.

2. Sosiologi kriminil, adalah ilmu pengetahuan tentang kejahatan sebagai suatu gejala masyarakat. Pokok persoalan yang dijawab oleh bidang ilmu ini adalah sampai dimana letak, sebab-sebab kejahatan dalam masyarakat (etiologi sosial) dalam arti luas juga termasuk penyelidikan mengenai keadaan keliling phisiknya (geografis, klimatologis dan meteorologis).

3. Psikologi kriminil, adalah ilmu pengetahuan tentang penjahat yang dilihat dari sudut jiwanya.

4. Psiko- dan neuropathologi kriminil, adalah ilmu tentang penjahat yang sakit jiwa atau uraf syarafnya.

5. Poenologi ialah ilmu tentang hukum dan berkembangnya hukuman arti dan faedahnya.

\footnotetext{
${ }^{6}$.R. Soesilo, 1985, Kriminologi (Pengetahuan Tentang Sebab-Sebab Kejahatan), Politeia, Bogor, hal1
} 
6. Statistik kriminil, ialah ilmu pengumpulan, penghitungan, pengukuran dan pengolahan angka gejala-gejala dalam kejahatan.

Dalam kriminologi ada beberapa aliran-aliran pemikiran, dan yang dimaksud dengan aliran pemikiran di sini adalah cara pandang (kerangka acuan, perspektif, paradigma) yang digunakan oleh para kriminologi dalam melihat, menafsirkan, menanggapi dan menjelaskan fenomena kejahatan. Oleh karena pemahaman kita terhadap dunia sosial terutama dipengaruhi oleh cara kita menafsirkan peristiwa-peristiwa yang kita alami/lihat, sehingga juga bagi para ilmuwan cara pandang yang dianutnya akan mempengaruhi wujud penjelasan maupun teori yang dihasilkannya. Dengan demikian untuk dapat memahami dengan baik penjelasan dan teori-teori dalam kriminologi, perlu diketahui perbedaan-perbedaan aliran pemikiran/paradigma dalam kriminologi.

\section{Kriminologi modern dikenal tiga aliran pemikiran untuk menjelaskan fenomena kejahatan, yaitu kriminologi klasik, positivis, dan kritis;}

1. Kriminologi klasik. Seperti halnya dengan pemikiran klasik pada umumnya yang menyatakan bahwa intelegensi dan rasionalitas merupakan ciri-ciri fundamental manusia dan menjadi dasar untuk memberikan penjelasan perilaku manusia, baik yang bersifat perseorangan maupun kelompok, maka

\footnotetext{
${ }^{7}$.R. Soesilo, 1985, Ibid, hal.4
}

$\begin{array}{lrr}\text { masyarakat } & & \text { dibentuk } \\ \text { sebagaimana } & \text { adanya } & \text { sesuai } \\ \text { dengan } & \text { pola } & \text { yang }\end{array}$ dikehendakinya. Ini berarti bahwa manusia mengontrol nasibnya sendiri, baik sebagai individu maupun masyarakat. Begitu pula kejahatan dan penjahat pada umumnya dipandang dari sudut hukum, artinya kejahatan adalah perbuatan yang dilarang oleh undang-undang pidana, sedangkan penjahat adalah orang yang melakukan kejahatan. Kejahatan dipandang sebagai hasil pilihan bebas dari individu yang menilai untung ruginya melakukan kejahatan. Dalam hubungan ini, maka tugas kriminologi adalah membuat pola dan menguji sistem hukuman yang akan meminimalkan tindak kejahatan.

2. Kriminologi positivis. Aliran pemikiran ini bertolak pada pandangan bahwa perilaku manusia ditentukan oleh faktorfaktor di luar kontrolnya, baik yang berupa faktor biologis maupun kultural. Ini berarti bahwa manusia bukan makhluk yang bebas untuk berbuat menuruti dorongan kehendaknya dan intelegensinya, akan tetapi makhluk yang dibatasi atau ditentukan oleh situasi biologis atau kulturalnya. Aliran pemikiran ini telah menghasilkan dua pandangan yang berbeda, yaitu "determinis biologis" dan "determinis kultural". Aliran positivis dalam kriminologi mengarahkan pada usaha untuk menganalisis sebab-sebab perilaku kejahatan melalui studi ilmiah ciri-ciri penjahat dari aspek fisik, sosial, dan kultural. 
Oleh karena kriminologi posotivis ini dalam hal-hal tertentu menghadapi kesulitan untuk menggunakan batasan undang-undang, akibatnya mereka cenderung untuk memberikan batasan kejahatan secara alamiah, yaitu lebih mengarahkan pada batasan terhadap ciri-ciri perilaku itu sendiri daripada perilaku yang didefenisikan oleh undangundang.

3. Kriminologi kritis. Aliran pemikiran ini mulai berkembang pada beberapa dasawarsa terakhir ini, khususnya setelah tahun 1960-an, yaitu sebagai pengaruh dari semakin populernya perspektif labeling. Aliran pemikiran ini tidak berusaha menjawab persoalan-persoalan apakah perilaku manusia itu "bebas" ataukah ditentukan, akan tetapi lebih mengarahkan pada proses-proses yang dilakukan oleh manusia dalam membangun dunianya di mana dia hidup. Dengan demikian akan mempelajari proses-proses dan kondisi-kondisi yang mempengaruhi pemberian batasan kejahatan kepada orangorang dan tindakan-tindakan tertentu pada waktu dan tempat tertentu. Pendekatan dalam aliran pemikiran ini dapat dibedakan antara pendekatan interaksionis dan pendekatan konflik. ${ }^{8}$

\section{Jadi secara etimologis, kejahatan diartikan sebagai perbuatan atau tindakan jahat, di mana suatu perbuatan dianggap sebagai kejahatan berdasarkan pada}

8 . Susanto, 1991, Diktat Kriminologi, Universitas Diponegoro, Semarang, hal. 1314 sifat perbuatan tersebut, apabila perbuatan itu merugikan masyarakat atau perorangan baik secara materil, misalnya mencuri, membunuh, merampok, memperkosa dan lainlain.

Adanya perbuatan yang dibenci dan mendapat reaksi dari masyarakat sebagai kejahatan. Tidak seorangpun menghendaki adanya kejahatan terjadi dalam lingkungan masyarakatnya, karena adanya kejahatan akan meresahkan dan merugikan kehidupan masyarakat. Oleh karena itu kejahatan harus diberantas dan ditanggulangi, salah satu cara penanggulangan kejahatan ini melalui penegakan hukum pidana.

Sebagaimana pengertian yang diberikan oleh Paul Moedikdo Moeliono, bahwa: "Kejahatan adalah perbuatan pelanggaran norma hukum yang ditafsirkan atau patut ditafsirkan masyarakat sebagai perbuatan yang merugikan, menjengkelkan sehingga tidak boleh dibiarkan. ${ }^{9}$

Perumusan tersebut di atas bahwa pengertian kejahatan meliputi semua perbuatan yang melanggar ketentuan hukum, yang dalam hal ini adalah hukum pidana sebagai hukum publik dimana perbuatan tersebut merugikan baik sikorban sebagai pihak yang menderita secara langsung perbuatan tersebut maupun bagi masyarakat sebagai pihak yang tidak secara langsung menderita perbuatan tersebut karena keamanannya terganggu.

Melihat aspek sosiologis pengertian kejahatan dapat dilihat dari pendapat R.Soesilo yang

\footnotetext{
9 .Soedjono Dirdjosisworo, Doktrin-Doktrin Kriminologi, Alumni, Bandung 1969, hal.13
} 
mengatakan: "kejahatan adalah meliputi segala tingkah laku manusia walaupun tidak ditentukan oleh undang-undang, tetapi oleh warga masyarakat dirasakan atau ditafsirkan sebagai tingkah laku atau perbuatan yang secara ekonomis atau psykologis menyerang dan melukai perasaan susila dalam kehidupan bersama. $^{10}$

W. A. Bonger, bahwa: "Kejahatan adalah perbuatan yang sangat anti sosial yang memperoleh tantangan dengan sadar dari negara yang berupa pemberian penderitaan (hukuman atau tindakan)". ${ }^{11}$

Selanjutnya kejahatan menurut A.S Alam adalah:

1. Dari sudut pandang hukum

Kejahatan adalah tingkah laku yang melanggar hukum pidana. Bagaimana jeleknya suatu perbuatan, sepanjang perbuatan itu tidak dilarang dalam perundang-undangan hukum pidana, perbuatan itu tetap dianggap sebagai perbuatan yang bukan kejahatan. Contoh perbuatan seorang wanita yang melacurkan diri. Dilihat dari defenisi kejahatan menurut hukum, perbuatan wanita itu bukan kejahatan, karena perbuatan melacurkan diri tidak dilarang dalam perundangundangan hukum pidana (KUHP), meskipun perbuatan itu sangat jelek bila dlihat dari sudut pandang agama, adat istiadat dan lain-lainnya.

\footnotetext{
${ }^{10}$.R.Soesilo, Kriminologi Pengetahuan Tentang Sebab-Sebab Kejahatan, Politea, Bogor, 1985, hal.13

11 .R.A.Koesnoen, Pengantar Kriminologi, Ghalia,. Indonesia 1977, hal.25
}

2. Dari sudut pandang masyarakat kejahatan adalah setiap perbuatan yang melanggar norma-norma yang masih hidup dalam masyarakat.

Pendapat tersebut di atas dapat disimpulkan bahwa pada perinsipnya kejahatan senantiasa mendapat reaksi dari masyarakat berupa sikap dari masyarakat yang tidak menyukai atau tidak membenarkan adanya tindakan tersebut hadir di tengah-tengah mereka. Itulah sebabnya dikatakan bahwa kejahatan merupakan perbuatan yang anti sosial baik perbuatan tersebut telah ditentukan oleh undangundang sebagai suatu tindakan kejahatan maupun semua perbuatan yang oleh masyarakat merupakan perbuatan yang patut dicela, karena masyarakat merasa dirugikan, menyerahkan hal ini kepada negara agar menindak pelaku kejahatan tersebut dengan harapan agar kelak perbuatan tersebut tidak terulang lagi. Hal ini diungkapkan oleh Van Bemmelen sebagai berikut: "Kejahatan adalah suatu tindakan anti sosial yang menimbulkan kerugian, ketidakpatutan dalam masyarakat sehingga dalam masyarakat terdapat kegelisahan dan untuk mententeramkan masyarakat negara harus menjatuhkan pidana pada penjahat, $^{12}$

\subsection{Perkembangan Kejahatan}

Saparinah Sadli, kejahatan atau tindak kriminal merupakan salah satu

${ }^{12}$.Soedjono. D, Op.Cit, hal.25 
bentuk dari "perilaku menyimpang" yang selalu ada dan melekat pada tiap bentuk masyarakat, tidak ada masyarakat sepi dari kejahatan. ${ }^{13}$ perilaku menyimpang itu merupakan suatu ancaman terhadap normanorma sosial yang mendasari kehidupan atau keteraturan sosial, dapat menimbulkan ketegangan individual maupun keteganganketegangan sosial, dan merupakan ancaman riil atau potensil bagi berlangsungnya ketertiban sosial. Dengan demikian kejahatan di samping masalah kemanusiaan ia juga merupakan masalah sosial.

Thomas Hobbes, ${ }^{14}$ masyarakat dikiaskan sebagai "manusia" besar di dalamnya manusia-manusia yang hidup bergaul berinteraksi dan interelasi. Louis Pasteur pernah pula "menempatkan" manusia sebagai "masyarakat" dan kejahatan sebagai bakteri yang mengerogoti tubuh manusia, maka pada masyarakat akan terjadi kejahatan "apabila" tubuh manusia itu lemah, jadi pada "masyarakat" yang "lemah" misalnya mengalami disorganisasi sosial, konflik-konflik budaya, anomie, dan lain-lain, katakanlah di masyarakat yang "awut-awutan", maka akan merajalela kejahatan, bagaikan bakteri atau virus yang menyerang tubuh manusia dan manusia itu akan sakit,

Banyak cara mempelajari kejahatan, bisa juga diumpamakan sebagai

${ }^{13}$.Saparinah Sadli, Persepsi Sosial Mengenai Perilaku Menyimpang, Bulan Bintang, Jakarta 1976, hal.56, merumuskan “perilaku Menyimpang” sebagai tingkah laku yaqng dinilai menyimpang dari aturanaturan normatif yang berlaku.

${ }^{14}$.Soedjono Dirdjosisworo, Anatomi

Kejahatan di Indonesia, Granesi, Bandung, 1996, hal.55 "manusia" yang jasmani rohani yang memiliki organisme tubuh yang dapat dipelajri melalui ilmu urai tubuh (organisme) atau dengan memperhatikan acuan anatomi. Dalam konteks ini bisa pula dikaitkan dengan action-theory (teori aksi) yang diketengahkan oleh Talcott Parsons (sosiologi Amerika kondang), yang intinya adalah, aksi atau prilaku manusia adalah suatu sistem, sebagai sistem aksi dipengaruhi oleh empat "sub sistem" organisme, sub-sistem identitas (pribadi), sub-sistem sosial dan subsistem budaya. Inilah sistem prilaku yang juga berlaku dalam kejahatan. ${ }^{15}$

Kejahatan sebagai masalah sosial tampaknya tidak hanya merupakan masalah bagi suatu masyarakat tertentu (nasional), tetapi juga menjadi masalah yang dihadapi oleh seluruh masyarakat di dunia, hal itu telah merupakan fenomena Internasional. Dikatakan sebagai masalah Internasional tidak hanya karena jumlahnya yang telah meningkat tetapi juga karena kualitasnya dipandang lebih serius dibanding dengan masa-masa yang lalu. Hal ini terlihat dalam salah satu pertimbangan Declarasi Kongres PBB ke empat tahun 1970 mengenai pencegahan kejahatan dan pembinaan para pelaku yang menyatakan. ${ }^{16}$ Believing thet the problem of crime in many countries in is new dimensions is far more serioes thet at any other time in the long history of these Congresses.

Kongres ke empat ini yang dibicarakan adalah masalah

\footnotetext{
${ }^{15}$ Soedjono Dirdjosisworo, 1996, Ibid, hal.55

${ }^{16}$.Soedjono Dirdjopsisworo, 1996, Ibid, hal 55
} 
kejahatan dan pembangunan.${ }^{17}$ Philippe de Seynes, anatara lain menyatakan kejahatan telah dianggap mempunyai ukuran-ukuran baru, tidak lagi dipandang sebagai suatu cacat kemasyarakatan (a cocial blemish). Sekarang kejahatan telah diakui sebagai suatu masalah socio politik, yang tidak hanya menuntut tindakan-tindakan yang bersifat teknis tetapi memerlukan tindakan luas yang disusun pada tingkatan politik yang tertinggi.

Akibat atau ancaman adanya kejahatan yang semakin meningkat itu, oleh kongres PBB keenam mengenai pencegahan kejahatan dan pembinaan para pelaku pada tahun 1980 di Caracas malahan dipandang cukup membahayakan kualitas lingkungan hidup. Oleh kareena itu tema sentral dari kongres ke enam ini ialah mengenai crime prevention and the quality of lefe. Dalam salah satu bunyi pertimbangan Deklarasi tahun 1980, antara lain dinyatakan; "menimbang bahwa fenomena kejahatan, melalui pengaruhnya terhadap masyarakat, mengganggu seluruh pembangunan bangsabangsa, merusak kesejahteraan rakyat baik spritual maupun material, membahayakan martabat kemanusiaan dan menciptakan suasana takut dan kekerasan yang merongrong kualitas lingkungan hidup.

2.3. Aspek Kriminologis Dalam Penanggulangan Kejahatan

Tidak seorangpun menghendaki adanya kejahatan dalam lingkungan

\footnotetext{
${ }^{17}$.Barda Nawawi Arief, Kebijakan Legislatief Dalam Penanggulangan kejahatan Dengan Pidana Penjara, Universitas Diponegoro, Semaramg 1994, hal, 2-3
}

masyarakatnya, karena adanya kejahatan akan meresahkan dan akan merugikan masyarakat, dan tidak hanya meresahkan ataupun merugikan harta benda, tetapi dapat mengancam keselamatan jiwa anggota masyarakat. Oleh karena itu kejahatan harus diberantas dan ditanggulangi dan salah satu cara penanggulangan kejahatan ini melalui penegakan hukum.

Usaha penanggulangan masalah kejahatan telah banyak dilakukan dengan berbagai cara, namun hasilnya belum memuaskan. Sebagaimana apa yang dikemukan oleh Habib -Ur-Rahman Khan dalam tulisannya yang berjudul Prevention of Crime-it is Society Which Needs The Treatmen and Not The Criminal, sebagai berikut; Salah satu usaha penanggulangan kejahatan ialah menggunakan hukum pidana dengan saksinya yang berupa pidana. Dan menurut Herbert L.Packer. ${ }^{18}$ usaha pengendalian perbuatan anti sosial dengan menggunakan pidana pada seseorang yang bersalah melanggar peraturan pidana, merupakan suatu problem sosial yang mempunyai dimensi hukum yang penting.

Dalam usaha penanggulangan kejahatan dengan aspek kriminologisnya ( Crime Prevention) maka hasil-hasil penelitian merupakan bahan-bahan bermanfaat sekali bagi penyusunan program pencegahan kejahatan oleh para penegak hukum.

Walter C. Reckless, ${ }^{19}$ mengemukakan beberapa syarat yang

\footnotetext{
${ }^{18}$.Herber L.Packer, 1968, The limits Of

Criminal, Standford university Press,

California, hal.3

${ }^{19}$.S oedjono Dirdjosisworo, 1984, Sosio-

Klriminologi (Amalan Ilmu-Ilmu Sosial
} 
perlu diperhatikan oleh pemerintah agar menanggulangi kejahatan dapat lebih berhasil, syarat-syarat tersebut adalah:

a. Sistem dan organisasi kepolisian yang baik

b. Pelaksanaan peradilan yang efektif

c. Hukum yang berwibawa

d. Pengawasan dan pencegahan kejahatan yang terkordinir

e. Partisipasi masyarakat dalam usaha penggolongan kejahatan.

Dari apa yang telah diuraikan tentang uisaha menanggulangi kejahatan telah jelas bahwa usaha Crime Prevention, ini meliputi dua segi penggarapan yakni:

a. Mencari faktor-faktor yang dapat menimbulkan kejahatan, yang dimulai dengan penelitian kejahatan atau kenakalan dalam lingkungan remaja, dan tentunya dalam berbagai pola-pola kriminalitas khusus, sehingga dengan penemuan faktor-faktor tertentu yang dihubungkan dengan berbagai faktor dapat menimbulkan kejahatan dapat memberi bahan untuk menyusun program penanggulangan kejahatan yang di antaranya diarahkan kepada penggarapan faktor-faktor yang bersangkutan.

Dalam pencegahan kejahatan yang ditujukan kepada faktor-faktor yang memungkinkan timbulnya kejahatan, atau dengan kata lain yang ditujukan kepada obyek yang menjadi sasaran penanggulangan terdapat dua cara yakni:

Dalam Studi Kejahatan) Sinar baru , Bandung, hal.138
1. Cara yang khusus yang sasaran penggarapannya terarah pada satu faktor tertentu yang telah diteliti, bahwa faktor tersebut sebagai faktor kriminogen. Cara ini dinamakan sistem abolisionistik yaitu penanggulangan kejahatan dengan menghilangkan faktorfaktor yang menjadi sebab musebab kejahatan. Cara ini sangat berhubungan dengan perkembangan studi tentang sebab-sebab kejahatan (etiologi kriminal), yang memerlukan pengembangan teori dan penelitian-penelitian lapangan.

2. Cara yang umum, yang ditujukan kepada anggota masyarakat secara keseluruhan dengan tujuan menebalkan iman dan kesadaran untuk tidak berbuat kejahatan. Cara ini dinamakan sistem moralistik, yaitu penanggulangan kejahatan melalui peneranganpenerangan keagamaan seperti, khotbah-khotbah da'wah dan lain-lain.

b. Meningkatkan kemantapan pembinaan hukum dan aparatur penegak hukum dalam rangka Law Enforcement, yakni suatu upaya memelihara dan membina hukum yang berlaku dalam masyarakat serta meningkatkan kemanpuan dan kemantapan aparatur penegak hukum, yang akan menegakkan hukum yang berlaku dalam masyarakat. Dengan kata lain ditinjau dari subyek yaitu penegak hukum.

Menurut Baharuddin Lopa, ${ }^{20}$ mengutip pendapat Kaiser di dalam

20 .Baharuddin Lopa, 1996, "Mencegah Kejahatan", Anatomi Kejahatan di Indonesia, Editor Soedjono Dirdjosisworo, 
buku Crime Prevention Strategies in Erope and North America yang disusun John Graham, 1990, mengatakan bahwa strategi pokok untuk mencegah kejahatan dapat dibagi tiga kelompok, yaitu primary, secondary dan tertiary prevention. Yang dimaksud Kaisar, ${ }^{21}$ dengan primary prevention ialah "as strategis which, through social, economic and other areas of public policy..." Sedangkan Secondary prevention ialah langkah-langkah yang berkaitan dengan criminal justice policy....". kemudian tertiar prevention merupakan langkahlangkah kongkret yang diambil kepolisian untuk mencegah terjadinya kejahatan, termasuk yang dilakukan para penjahat kambuhan.

Selanjutnya, Baharuddin Lopa, ${ }^{22}$ mengatakan, bahwa dari ketiga kelompok pencegahan kejahatan ini, langkah primary prevention paling efektif. Karena tak dapat dimungkiri, sesungguhnya kalau kita ingin mencegah kejahatan akar penyebabnyalah yang perlu dieliminasi terlebih dahulu. Masih terlalu banyak bukti bahwa ketimpangan sosial ekonomi merupakan salah satu penyebab terjadinya kejahatan.

Dengan upaya preventif menitikberatkan pada tindakan sebelum tindak pidana terjadi. Mengingat upaya penanggulangan tindak pidana lewat upaya preventif lebih bersifat pencegahan sebelum terjadinya kejahatan, maka sasaran utamanya adalah menangani faktorfaktor kondusif antara lain berpusat

Granesia Bandung, hal.220. Lihat pula

Mencegah Kejahatan, Gatra, 1 Juni 1996

${ }^{21}$ Ibid, hal.220

22 .ibid, hal.220 pada masalah atau kondisi-kobdisi sosial yang secara langsung atau tidak langsung dapat menimbulkan atau menumbuhsuburkan kejahatan.

\section{Kesimpulan}

Penanggulangan masalah kejahatan telah banyak dilakukan dengan berbagai cara. Dalam usaha penanggulangan kejahatan dengan menggunakan hukum pidana dengan sanksinya yang berupa pidana.

Dalam usaha penanggulangan kejahatan dengan aspek kriminologis (Crime Prevention), maka penelitian merupakan bahan-bahan bermanfaat sekali bagi penyusunan program penanggulangan kejahatan. Usaha penanggulangan ini meliputi yaitu mencari faktor-faktor yang dapat menimbulkan kejahatan yang dimulai dengan penelitian kejahatan, sehingga dengan penemuan faktorfaktor tertentu yang dihubungkan dengan berbagai faktor dapat menimbulkan kejahatan dapat memberi bahan untuk menyusun program penanggulangan kejahatan yang di antaranya diarahkan kepada penggarapan faktor-faktor yang bersangkutan.

\section{Daftar Pustaka}

A.S.Alam, Kejahatan, Penjahat dan Sistem Pemidanaan, Diktat,tth,Unhas, Makassar

Baharuddin Lopa, 1996, Mencegah Kejahatan, Anatomi Kejahatan di Indonesia, Editor Soedjono Dirdjosisworo, Granesia, Bandung

Barda Nawawi Arief, 1994, Kebijakan Legislatif Dalam 
Penanggulangan Kejahatan Dengan Pidana Penjara, Undip, Semarang 2007, Masalah

Penegakan Hukum dan Kebijakan Hukum Pidana Dalam Menanggulangi Kejahatan, Kencana Pernada Media Group, Jakarta

Herbert L.Packer, 1968, The Limits Of Criminal Standford, University Press, California

I.S.Susanto, 1999, Paradigma Hukum Yang Berdaulat Dalam Wacana Politik Hukum dan Mulyana W.Kusumah, Pustaka Pelajar, Yogyakarta

-------------, 1991, Diktat Kriminologi, Fakultas Hukum Universitas Diponegoro, Semarang

R.A.Koesnoen, 1977 Pengantar Kriminologi, Ghalia, Indonesia
R. Soesilo, 1985 Kriminologi Pengetahuan Tentang Sebab-Sebab Kejahatan, Politea, Bogor

Saparinah Sadli, 1976, Persepsi Sosial Mengenai Perilaku Menyimpang, Bulan Bintang, Jakarta Soedjono Dirdjosisworo, 1969, Doktrin-Doktrin Kriminologi, Alumni, Bandung ,1984, Sosio-Kriminologi (Amalan IlmuIlmu Sosial Dalam Studi Kejahatan) Sinar Baru, Bandung 1996 , Anatomi Kejahatan di Indonesia, Granesi, Bandung

Sthephan Hurwitz, 1982, Kriminologi, Saduran Ny.L.Moeljatno, Bina Aksara, Jakarta 